\title{
PPP3CA wt Allele
}

National Cancer Institute

\section{Source}

National Cancer Institute. PPP3CA wt Allele. NCI Thesaurus. Code C49425.

Human PPP3CA wild-type allele is located within 4q21-q24 and is approximately $324 \mathrm{~kb}$ in length. This allele, which encodes serine/threonine-protein phosphatase 2B catalytic subunit alpha isoform protein, is involved in calcium-dependent, calmodulin-stimulated protein dephosphorylation. The PPP3CA gene is associated with susceptibility to cardiac hypertrophy. 